\title{
Nicola Dusi
}

University of Modena and Reggio Emilia (Italy)

Don Quixote, Intermediality and Remix. Translational Shifts in the Semiotics of Culture

\begin{abstract}
Intertextual relationships as active dialogue between texts and cultures are the starting points of an analysis of the concepts of intermediality, cross-mediality and transmediality in Lotman's terms of "semiosphere".

Then, in the second part, brief semiotic analyses will be presented in order to investigate

a few mechanisms of the intermedial and transmedial network, starting from Don Quixote by Cervantes and moving to cinema and new digital media through adaptations, remakes and movie remixes.
\end{abstract}

\section{Keywords}

Intermediality, cross-mediality, transmediality, adaptation, remake, remix, media, semiotics, translation

\section{Explosions in intertextual processes}

One of the most interesting contributions of Lotman's Tartu School is its ongoing 
research on dynamic models of semiotic systems and the establishment of a full-fledged "semiotics of culture". Before dealing with the translations, re-workings and remakes from the vantage point of a semiotics of culture using the example of intermedial transformations of Don Quixote by Cervantes, a rivisitation of some of Lotman's ideas about the ambivalence of texts in translation may be useful. An important issue is Lotman's wholehearted acceptance of the indeterminacy of texts, given that "every real text has an inherent propensity to incorrectness" (Lotman, 1977: 202). Semantic ambivalence itself is regarded as a crucial factor in the dynamics of a system, according to Lotman: "the growth of internal ambivalence corresponds to the moment of the system's transformation into a dynamic state" (Lotman, 1977: 204). ${ }^{1}$

Lotman's suggestion leads us to consider semantic indeterminacy and ambivalence as a key factor in every translation and reinterpretation from literary texts to movies, namely, in our perspective, adaptations and remakes from a literary source. According to Lotman's theory, one of the pivotal functions of the æsthetic text is to "produce new meanings" (Lotman, 1994: 378). To Lotman a semiotic system is first and foremost a semiotic space with an "internal irregularity" (Lotman, 1984), in which languages organize themselves hierarchically. And a text is considered a "generator of meanings" (Lotman, 1994: 378), which needs a dialogic relationship in order to trigger itself off. According to Lotman (2009) a kind of "explosion" would occur, at semantic level, when a text enters into a pragmatic relationship with another, which may even be a new 
cultural context or a new reader. The semantic world of a text transforms itself and produces new meanings that may have been possible but not "actualized", namely effectively used. The introduction of an extraneous semiosis changes the entire semiotic situation in a text and its context (Lotman, 1994: 378). The translational comparison of a source text with a target text will thus be carried out at various layers of the texts within a complex network of strategies of difference and equivalence given by the various constraints of the process, such as for example the enunciative choices and attention to the contexts of the viewers of every cinema adaptation and every remake.

However, there are not only moments of "explosion" and sudden transformation in cultural development. According to Lotman ( 2009: 24) there are layers which have developed at different speeds and in some instances explosions may go together with a gradual development, in a sort of figure-and-background game. Semiospheres of art and culture would therefore always present a simultaneous combination of explosive and gradual processes.

By making reference to Lotman and structural anthropology (Lévi-Strauss, 1958), French post-structural semiotics (Floch, 2000; Fontanille and Zilberberg, 1998) suggests that at the basis of the functioning of cultures and text constructions there is a bricolage meant as "praxis énonciative". A practice drawing from cultural memory cultural forms which have settled deep into the 'back' in order to dig them out, rework and recontextualize them. Today consumers and producers of movie remixes in the Web re- 
propose a similar mythical logic, by exploring its irregular objects, texts and their fragments, in order to play with new intertextual and participatory relations of meaning (Tryon, 2009: 149-151).

In this article I suggest that the problems of indeterminacy and complex intertextual relations opened by Lotman could be partly 'solved' by a comparative analysis of texts using an "intersemiotic approach" (Torop, 2000; Dusi, 2000; Eco, 2001) in order to check the levels of translation and the network of "hypertextual" relations (Genette, 1982). My methodological proposal is to work on intermedial "isotopies", as I will further explain, considering both the plane of content and the plane of expression, and their mutual relation, in every artistic text.

In a process of adaptation the literary text is semiotically 'activated' (through scripts and scenarios) and, thanks to the filmic treatment, the text or novel goes through a 'revitalization' of its hermeneutic kits. Using Lotman's approaches we could consider the inverse relationship, namely when the literary text is compared to an adaptation which sometimes becomes a sort of progenitor of a series of remakes, sequels and other reinterpretations. Every text of these series reopens the semantic indeterminacy of the novel and its textual complexity while proposing an implicit reworking of the translational choices of the so-called progenitor. According to Torop and Saldre (2013), Lotman defines the core mechanism of cultural innovation in translating cultural elements across its existing systemic boundaries. Intertextuality in this way (see 
Kristeva, 1994) becomes a polyphonic and multilayered dialog among diverse textual and discursive meanings which may also take place within the same text through conflict, clash, intersection and information exchange between different traditions, different subtexts, and different interpretations, as is the case for the heterogeneous chain of reinterpretations, remakes and adaptations of a literary text, such as Don Quixote.

\section{Hypertextuality and remakes}

Notions of "hypertextuality" and "transtextuality" proposed in Genette's narratology could be considered an essential component of the process of definition of the identity of every text and culture. According to Genette's Palimpsestes "transtextuality" refers to all that which puts "one text in relation, whether manifest or secret, with other texts" (1982: 1, My Translation). Genette proposes five well-known types of transtextual relations: from "intertextuality" (quotation, plagiarism, allusion) to "hypertextuality" (together with "paratextuality", "metatextuality", "architextuality"). Discussing these relations, Stam (Stam et al., 1992: 209-210) reopens the idea of "paratextuality" and considers for example "the original variant versions of films" (before cuts and final editing due to different historical or political constraints) as part of the paratext of a film. Talking about "hypertextuality", Stam argues that transtextuality refers to "the relation between one text, which Genette calls hypertext, to an anterior text or hypotext, 
which the former transforms, modifies, elaborates or extends" (1992: 209-210). ${ }^{2}$ Applying this concept to cinema, Stam evokes "those films which derived from preexisting texts in a way more precise and specific than that evoked by the term intertextuality" (Stam et al., 1992: 209-210), as for example filmic adaptations, that are "derived" texts which transform the source (hypo)text "by operations of selection, amplification, concretization and actualization" (Stam et al., 1992: 209-210). In this way, the relations of a derived text with its source text could be multiplied: according to Stam, the diverse filmic adaptations of Don Quixote (Pabst, Welles, Gutierrez Aragón, and so on) can be seen as "variant hypertextual 'readings' triggered by an identical hypotext" (Stam et al., 1992: 209-210). Moreover, the diverse prior adaptations "can come to form part of the hypotext available to a film-maker coming relatively 'late' in the series" (Stam et al., 1992: 209-210).

\section{Intermediality and transmediality in an intersemiotic continuum}

The growing international recognition of the concept of intermediality points to different views on medial border-crossings and hybridization and on the materiality and mediality of artistic practices and of cultural practices in general. "Intermediality" designates those configurations which have to do with a crossing of borders between media, and an Intermedial Turn has been evoked with studies dealing with intermediality both in the broad sense of all kinds of phenomena that involve more than 
one conventionally distinct medium of expression, and in the narrower sense of a specific quality or individual artefacts or cultural products in which signification is conveyed by more than one medium (Wolf, 2002: 15).

Rajewsky (2005: 51-52) suggests a preliminary typology: intermediality as medial transposition (as in film adaptations, novelizations, and so forth); intermediality in the narrower sense of media combination (the so-called multimedia or mixed media); intermediality as intermedial references, for example references in a literary text to a film through, for instance, the evocation or imitation of certain cinematic techniques, ekphrasis, references in film to painting and so forth.

While the variety of aspects relating to the concept of intermediality makes it difficult to reach a real general overview, ${ }^{3}$ this article attempts to show that intermediality can be "a bridge between medial differences which is founded on medial similarities" (Elleström, 2010: 12), and in this perspective could become a synonym of "intersemiotic translation" (Jakobson, 1959).

Italian and French sociosemiotics of media (Eugeni, 1999; Odin, 2000) investigate the rules of any mediatic "discourse", conceived as a social and textual reality, culturally defined and semiotically articulated in forms, processes and practices of signification. For example every film is considered as a text that works by activating and selecting a network of social knowledge from the historical to the private dimension, by way of the intertextual and the metatextual competences (namely cultural encyclopaedias) of every 
spectator. Intermedia studies involve the embodied strategies of medial experiences (Casetti, 2008) such as the process of transferring meanings and affects (emotions) from one medium to another, considering them as both problems of intersemiotic translation and problems of interpretation (Eco, 2003; Dusi, 2010).

The appearance of digital technologies has opened up entire new worlds of repetition and remix and mash ups practices (Jenkins, 2006; Lessing, 2008; Manovich, 2007; Sonvilla-Weiss, 2010). From a sociosemiotics point of view, an intermedia perspective will consider a plethora of texts with a network of shared references and translations. A single literary, visual or audiovisual text, or a group of texts, will always have a series of references which are constantly in translation with each other. Intersemiotic translations or transpositions from novel to film are possible provided that source text and target text are analysed in terms of what is not a variation (see Arvidson and Askander et al., 2007; Dusi, 2010). Remaking too appears as an intermedial, interpretative and transforming strategy that, to a greater or lesser extent, can construct and maintain explicit ties with a source text using it as a storehouse or archive of structural invariants, at the levels of expression and content. This is why we could define 'intermediality' as a wider process of intersemiotic translation. Intermediality could contain both a general logic of adapting and remaking when dealing with the idea of similarity and equivalence of meanings between source and target texts, and a more interesting perspective that considers differences and transformations of every 
individual transposition and remake analysed as cultural textual products.

According to Jenkins (2011) "transmedia, used by itself, simply means across media. Transmedia, at this level, is one way of talking about convergence as a set of cultural practices". Jenkins has recently reopened his famous definition of transmedia storytelling given as "a process where integral elements of a fiction get dispersed systematically across multiple delivery channels for the purpose of creating a unified and coordinated entertainment experience", and where "ideally, each medium makes its own unique contribution to the unfolding of the story" (Jenkins, 2007).

Transmedia storytelling, states Jenkins (2011), describes the "further development of the storyworld through each new medium" and talks about "the flow of content across media [...] and the networking of fan responses", with a logic which "encourages cocreation and collaboration" (Jenkins, 2011). A very similar term, quite a synonym, is "cross-media". Both are referring to "inter-related and integrated media experiences that occur amongst a variety of media" (Davidson et al., 2010: 24) but, according to some scholars, cross-media communications emphasize interactivity, because they "require a pro-active role by the audience to interact with the experience and get more directly engaged and involved" (Davidson et al., 2010: 24), as for example in video games. Jenkins distinguishes between "adaptation" and "extension" and gets more to the point of our discussion: 
"Basically, an adaptation takes the same story from one medium and retells it in another. An extension seeks to add something to the existing story as it moves from one medium to another" (Jenkins, 2011, My Italics).

We could probably talk about intermediality in the first case and about transmediality (or cross-mediality) in the second. Nevertheless, adaptation and remake are not simply operations of "retelling" the same story, as Jenkins explains quoting Dena (2009), who considers adaptations as "interpretations" that "may be highly literal or deeply transformative" (Jenkins, 2011). Moreover, translating from a novel to a movie means to significantly expand and extend the story in the process of cinematic representation, and "the shifts between media mean that we have new experiences and learn new things" (Jenkins, 2011). Dena's perspective seems quite close to Stam's narratology (Stam et al., 1992) and even to Eco's suggestion of adaptation as an "intersystemic interpretation" where there is "a decided step from purport to purport of the expression" (Eco, 2001: 118), every interpretation is a result of local textual negotiations and adapting always means "showing things left unsaid" by the novel (Eco, 2001: 121). Jenkins concludes in a Solomonic way: adaptation and extension are two theorical poles of a continuum that includes the real processes of textual recreation and transformation. In these terms, transmedia storytelling would become a serial narrative form of intermedial expansion, variation and proliferation. It differs from a general 
understanding of intermediality which, in our hypothesis, mostly considers intertextual links of continuity and equivalence in inter and intrasemiotic translation.

In any case, Torop and Saldre (2012) consider the issue of "the modeling influence of media" in terms of intersemiotic translation:

"this translation process $[\ldots]$ is the building principle of all transmedia texts, no matter whether they are transmedial at birth, extended to be transmedial after the initial success or regarded as transmedial post factum in the cultural memory" (Torop and Saldre, 2012: 32).

I totally agree with this suggestion, to which I would add some specific hypotheses about inter and intrasemiotic processes.

Remakes and movie trailers as intrasemiotic translations

According to Lotman (2001, 2009), translation and its mechanisms are the basis for all relations between semiotic systems of signification and communication. It works not only for the linguistic system but also for the intersemiotic transmutations between literature and cinema, cinema and theater as well as painting and cinema, and so on. Moreover, intersemiotic translation is a complex form of action. Jakobson's formula which states that "intersemiotic translation or transmutation is an interpretation of 
verbal signs by means of signs from nonverbal sign systems" (Jakobson, 1959: 261) is useful to describe adaptations. But intersemiotic translation is not just a simple 'transcodification': it is always a cross-cultural, dynamic and functional event (Reiss, 1983) caught between the requirement to remain faithful to the source semiotic system, and the need to transform it into a new, different text (visual or audiovisual or multimedia) that aims at being understood and accepted in the target culture (Dusi, 2010; Torop, 2000; Toury, 1980).

In this perspective, film remakes with a literary source compound the intersemiotic problems with that of a different form of translation, namely an "intralingual translation" (Jakobson, 1959: 261) or better still, an intrasystemic one (Eco, 2001: 106). When an "intralingual" translation is, according to Jakobson, "an interpretation of verbal signs by means of other signs of the same language", like "rewording" (1959: 261), I would argue that "rewording" exists in audiovisual media in different forms, more condensed or more expanded, as for example with movie remakes and trailers. Eco (2001: 117) calls "rewritings" in literature and in music "intrasystemic interpretations" within the same language. I would call them intrasemiotic translations considering film remakes as secondary texts that reopen the semiotic system of the source film for a new and independent text, mostly reworking the "same" matter of expression and content. Movie remixes of the web 2.0 are also, in this perspective, short audiovisual texts resulting from an intrasemiotic transformation of the movies. In a remix the narrative 
and communicative design usually conveys values and topics and narrative forms that shift from the sphere of the movie production to the sphere of the audience. According to Lessing (2008) and Manovich (2007), nowadays "remix" has a broad meaning of transformation, re-editing, collating or overlapping the original with other pictures, sounds, videos or music, and sometimes remix practices are just simple playful practices of consumption and re-appropriation. Looking closely at new media products, user-generated contents and media sharing are mostly remix, mash-up and collage aiming at creating something new with practices of bricolage and recycling (Navas, 2012; Tryon, 2009). ${ }^{4}$ Manovich $(2007,2013)$ would call them cultural products of a "Deep Remixability", the global contemporary aesthetics in digital media. Also in a sociosemiotic perspective (Dusi and Spaziante, 2006) these creative and shared practices of remaking and reworking - re-using archives of music, images, audiovisual and multimedial cultural products - could be considered forms of contemporary transmediality. In this way intermediality and trasmediality can be studied as a dynamic cultural ensemble of intersemiotic relations between texts, between similarity and difference. In many across-media translations, as in movie and paintings, Cervantes's two novels (the first and its sequel) become a matrix of invariants for new recombinations and a set of possibilities for further transformations.

When dealing with a galaxy of interrelated texts in a network of relationships and crossreferences, a network that coexists with, and transcends, translational and interpretive 
processes, it is worth recalling that the profound hypertextual dimension of each cultural system, understood as a set of portions of diverse textualities connected to each other, was put forward by Lotman (1984) in his "semiosphere" theory.

According to Lotman $(1984,2001)$ a "semiosphere" is understood as a living organism with its own boundaries and center, with up and down fluctuations, energy differences and attraction and aversion processes. Whence "the simultaneous combination of explosive and gradual processes in the various spheres of culture" (Lotman, 2009: 12), namely with continuous and discontinuous movements of comparisons, clashes and partial assimilation between texts and cultures. Lotman's proposal allows us to understand the transposition of texts in at least a bidirectional way or, better still, as a multidirectional and global interaction given by today's digital media. It is not only the source text that sets the rules of the translation game but the target text which answers and produces new hermeneutic meanings that enter the semiosphere and affect the source text.

This is a well-known intertextual mechanism in narratological studies, where scholars refer to a "rebound effect" (Costa, 2002; Genette, 1982). Adaptations and remakes enter in a mesh of reciprocal quotations, allusions and they "resonate" together with other texts and other media. Sometimes they create an indelible feedback effect on the source text because of their interpretation, indeed this becomes a process that confers new meaning, which we might call, following Lotman (2009), a re-semanticization. 
We could no longer read Cervantes without having in mind some iconic inventions and characters created by Pabst's musical or the unfinished films by Orson Welles or Terry Gilliam. In the case of a literary source text such as Don Quixote, the translational intermedial mesh begins with the first illustrations of the novel, which would later become paintings, theatrical texts and performances, dance and musical representations, then (almost simultaneously) becoming comics and photos, and in progression movies and cartoons, TV series, advertising and so on, until we eventually find them quite preserved and 'coherent' in the new media discourse as in remix trailers. They give new interpretations, and transform the original source text for their own purposes even while keeping it immediately recognizable. These crossmedial products belong to our postmedial universe of "remediation" (Bolter and Grusin, 1999), especially in the digital age of the computer as a "metamedium" where the logics of software create cultural and aesthetic products and habits (Manovich, 2001). All these signs, texts, practices and cultural products, albeit only "fragments" of a more complete narration, could be potentially linked with one another. In a sociosemiotic way, every text within this mesh has in memory the others. Following Lotman (1984), we could say that translation mechanisms construct and at the same time make cultural universes dynamic because differences and transformations circulate, and innovations can occur.

According to Lotman $(1984,2001)$, even a single text is seen as a condensed program of a whole culture, in some mirror (isomorphic) relations. Cultural systems evolve and 
change through processes of translation, assimilation and dislocation. Hence, studying inter- or intrasemiotic relations between some source texts and a network of target texts, means to find micro-models of some macro-cultural systems.

\section{Crossmedial isotopies and sociosemiotic heroes}

From the very beginning of the history of cinema we can find more than fifty movies adapted from Cervantes's novels. Pabst, Kozintsev, Grimaldi, Gutierrez Aragòn, Welles, Yates, are some of the directors of the more recent impressive list of adaptations and remakes who have tried to adapt Cervantes's The Ingenious Gentleman Don Quixote of La Mancha (1605-1615) and to create a new and autonomous cultural product every time. Although such movies are set in different historical contexts and make different translational choices, they maintain a strong link with the narrative and fictional world of Cervantes - something 'invariant' that allows every critic and viewer to recognize the main characters, their values and their iconic descriptions, as if they had a consistently recognizable 'mythical identity'.

As Nabokov (1983) remarked, there is "mythism" in the characters of Don Quixote and Sancho Panza as they create a set of qualities that are the opposite of each other and resolve, at imaginary level, the contradictions of real life.

Tall and short, thin and fat, wiry and rounded, these are semantic and expressive categories used in Cervantes's novel to describe the two heroes on their different rides, 
the horse and the donkey, one armed (Don Quixote) and the other unarmed. A famous drawing by Picasso (1955) perfectly captures the iconic force of these semantic oppositions.

Sancho droops down, towards the earth, rather than up to the sky like his master. In the first book in particular, Quixote sways between reality and its insane misrepresentation, which includes sophistication of arguments and fantastic Baroque and chivalrous explanations of the world. Sancho, conversely, is credulous but realistic, tied to primary needs, but he too is a dreamer of exotic treasures. In the second book these qualities seem to have been swapped around. These are some of the essential features, almost a physiognomic and psychological caricature, which made the intermedial fortune of the pair of characters giving them quite an independent existence from the novels (Riley, 1988) which allows them to go through the texts and the most diverse cultures while maintaining an immediate effect of recognition.

Don Quixote and Sancho are therefore a pair of sociosemiotic heroes, or better still, of "massmedia Übermenschen" (Eco, 1979), who are defined in terms of their multiple inter- and transmedial variants from literature to comic books, to movies, to TV series, to cartoons, and so on. The sociosemiotic approach to translation (Dusi, 2000; Marrone, 2005) calls "intermedial isotopies" these platforms of continuity and coherence between several texts. These are semantic invariants that lead us safely through literature, movies, television series or the Web functioning as instructions to recognize massmedia 
heroes thanks to their mythical qualities. ${ }^{5}$

According to Lotman (2009), it is not just the translational area that is interesting in a cultural and textual comparison but what remains out of the game, that is to say the area of difference and "nontranslatability" (Lotman 2001: 36-37). It is this area that invites to a semiotic effort and challenges the languages to create innovation and different ways to translate. Cultural and textual boundaries are not just limits but always invitations to look for new solutions.

Textual semiotics of translation (Eco, 2001) proposes to study the relationships of negotiation between who is uttering and who is receiving. If enunciation is a strategy of the text that creates the Model Author and the Model Reader (Eco, 1979) and organizes the knowledge required by a reader in order to be able to interpret one specific text, a partial and "local encyclopedia" is a universe of discourse defining the possible interpretations and translations of a specific text (Eco, 1990). Enunciation also functions as a bridge between the different levels of the text and the relationships between the product of enunciation, and its strategies create discursive differences in cultures (Eco and Nergaard, 1997). In an intertextual perspective, narrative, thematic and figurative (iconic) "isotopies" become 'guidelines' (semantic instructions) that allow the reader or the viewer to immediately recognize heroes across media and, together with the wider rules of the discursive genre, somehow predict their actions.

According to Jakobson (1971), we can have translation shifts using the guideline of a 
textual "dominant", which may become a tool for the analysis of the translational passages to different textual levels in order to achieve different possibilities of equivalence to the source text (Torop, 1995: 330, It. Tr.). The problem is always to decide which levels of semantic consistency (i.e. 'isotopies') could become dominant and transform the target text considering the semiotic universe of the target culture (Toury, 1980).

In every intercultural translation, however, the most important changes affect the points of view regarding the cultural values and the genre (Altman, 1999) that orient the target text and its semiotic system and dictate the rules of the game, creating differences within a chain of adaptations and remakes. A chain that may include many film musicals and parodies in the case of Don Quixote.

\section{Don Quixote and the windmills in literature and pictures}

According to Giménez-Frontín (2005), the first illustrations of the novel show a Don Quixote who is a "strongman, irascible, violent, and even frightening" (Forgione, 2005: 16, My Translation) and the novel by Cervantes became popular with this first type of Quixote until the $18^{\text {th }}$ century. It is only in the second part of the novel that the description of Don Quixote as dry, tall and thin fits the way he is represented, in paintings by Dalí and Picasso. The transition from the first representations to those of the $20^{\text {th }}$-century Quixote takes place gradually, thanks to the illustrations by Gustave 
Doré (in 1863) and especially the paintings by Daumier. These are part of the iconographic sources that influence directors like Pabst, Gutierrez Aragón, Welles, who tried to recreate Spanish atmospheres and classical iconography in the choice of the set and the main characters. Some micro aspects of space, time, rhythm, narrative and enunciation strategies will help us to gain a better understanding of Cervantes's literary narrative mechanisms that have been delivered in different ways in movies as well as in many illustrations and paintings. The adventure of the windmills is probably "the one with the most frequent allusions in popular versions and illustrations" (Riley, 1988: 105). There is remarkable narrative economy: Cervantes could not be more concise, with an emphatic attack on the machine (the new technology of the time) by a man who, in his own mental representation, is an hidalgo who holds on to tradition (Riley, 1988: 105). Riley states that a way to build "visuality" in Don Quixote is to provide the reader with a "duality of perspective" (Riley, 1988: 106). Due to Don Quixote's "peculiar madness" (Riley, 1988: 106), the reader is repeatedly advised or indirectly reminded of the way things and people look (including the knight himself).

This happens also in the windmills sequence. We read a dialogue between Don Quixote and his servant: the former claims to see something in terms of how he imagines it and the latter replies, albeit with a certain naïveté, with what he sees in reality. But the omniscient narrator, who presents the scene, informs us: "At this point they came in sight of thirty forty windmills that there are on plain" (Cervantes, VIII: 75). ${ }^{6}$ The 
perspective guiding the story is thus realistic and presents us a world of credible and believable "facts". The narrator is on the side of Sancho and the reader can only adopt almost spontaneously - this 'objective' viewpoint.

The narrator's perspective in the story is already set with a temporal and spatial knowledge of the world. It stages a 'localized' gaze: the viewing point is in fact from a distance. Hence, narration begins with something like a 'long shot', in which the two heroes stand out in the foreground and the windmills in the background (far away): an objective point of view in which actions are seen from the outside even though already set in a specific timeframe. What happens then? Firstly, we distinguish the point of view of Don Quixote from that of Sancho. Don Quixote sees, shows, decides: the focus of the story moves quickly from the 'objective' perspective to his 'subjective' intention to start a battle. The reader gets into the reasoning of Don Quixote who already sets himself up as a winner, morally justifies his actions and denigrates his opponent. There follows the dazed answer by Sancho ("What giants?"). The question is not only what to "watch" but also the shift towards a conflict about their "knowledge".

Shortly before the collision with the windmill the story swerves back to an objective point of view to inform us that the wind is suddenly moving the sails "A slight breeze at this moment sprang up, and the great sails began to move" (Cervantes, VIII: 75). The clash between the knight (with his horse) and the machine is then played out in the alternation of voices between the omniscient narrator and the subjective gaze of Don 
Quixote, who shifts from vision to hearing (the cries of Sancho in the distance, his own loud cry) and a dramatic physical contact. His riding off into the windmill - a quick movement with a linear direction in space - turns into a sensory approach and a proximity of different 'bodies', conveyed as a cinematic close-up.

"So saying, [...] with lance in rest and covered by his buckler, he charged at Rocinante's fullest gallop and fell upon the first mill that stood in front of him; but as he drove his lance-point into the sail the wind whirled it round with such force that it shivered the lance to pieces, sweeping with it horse and rider, who went rolling over on the plain, in a sorry condition." (De Cervantes Saavedra, VIII: 75, Engl. Transl.) $)^{7}$

It seems that the centrifugal force of the sails were 'absorbed' by the knight. It is true that he is first lifted up and then thrown off with violence, but the direction of Don Quixote's powerful horizontal thrust through space has been transformed and suddenly becomes circular. That is why he is sent "rolling" away.

Quixote through movies and remixes

Of the many different adaptations, remakes and re-adaptations, sequels and parodies of Cervantes's Don Quixote, including the failures described in Lost in La Mancha by Fulton and Pepe (GB/USA, 2002), a documentary on Terry Gilliam's attempts in 
making a never-born film, I have chosen a few examples that seem useful to illustrate sociosemiotics and Lotman's theories of texts as cultural products. These are Don Quixote by G.W. Pabst (GB/FR, 1933); Jess Franco's edition of filmic materials by O. Welles: Don Quijote de Orson Welles (USA, 1955-1992); and Don Quixote by Peter Yates (USA, 2000). Finally I will examine some digital remixes.

Don Quixote by Pabst (1933) selects a few episodes from the original text and puts at the end both the 'fight' with the windmills and the burning of Quixote's library, which recalls what the Nazis were doing in those years. The film opens with some cartoons by Lotte Reiniger but seeks a realistic viewpoint, despite strong expressionistic features in the use of shadows looming over the hero. Pabst risked not finishing the movie due to lack of funds, as it happened many years later to Welles and Gilliam (Gilliam called it "the curse of Quixote"). Pabst solved the problem of the missing scenes with arias, sung by the languid protagonist: the bass singer, Feodor Chaliapin who had previously played Quixote in an opera by Massenet (in 1910).

Pabst's recourse to an adjustment and reconfiguration of his project due to economic problems, enables us state that intermedial relations are built in a dynamics which is not only intertextual, but also "contextual" (Lotman, 2009: 1), meant here as economic and social constraints. In the scene of the windmills Pabst's film is faithful to the rhythm and spatiality of the novel, as well as the alternation of objective and subjective gaze, but we never enter into the mind of Don Quixote. However, there is an important 
iconographic invention: Don Quixote remains suspended for a long time, hanging by his spear, to the sails of the windmill rotating slowly several times. It is a cinematic invention, which represents an iconic translation of the clash of forces and the victory of the machine's centripetal force over the human character. An iconic invention that becomes the matrix of a long chain of transpositions and remakes. ${ }^{8}$

The 'expansion' due to the treatment and adjustment process explains how in the translation even the meaning of the source text is thus enriched. The boundaries of semiotic systems partially "overlap" (Lotman, 2009) and the iconic (figurative) level, with its abstract 'figural' and rhythmic components, create new connections between novel and film in a dialogic relationship.

How have Cervantes's double gaze and double narrative perspective, and the resulting contrast between the narrator's realism and the fantastic visions of Quixote, been translated into films? Pabst's film transposes Cervantes's first book in particular and swings between comedy and the grotesque, opting for a realism with musical moments of rêverie.

The choice made by Orson Welles, twenty years later, is more fascinating. In the scene of the windmills, Welles edits alternately a realistic objective gaze, external to the action, with an hallucinated gaze: the inner subjective gaze of the delirious hero. So Quixote here is confronted with extreme close-ups and details of grotesque toothless faces taken from the paintings by Goya, together with scary sounds of laughs. Welles 
does not follow Pabst's invention and goes back to the context of the original sources: Quixote, in fact, is unseated and falls down (without rolling) as described in most of the traditional iconography.

As previously mentioned, Don Quijote by Orson Welles is largely a movie edited by J. Franco, yet it is currently the most complete of the many attempts to save the huge quantity of shootings by Welles during the Fifties and the Sixties in Mexico, Spain and Italy. Actually, it is a (pre-digital) remix (or, better, a mash up) of many heterogeneous materials as backstage scenes and documentaries shot by Welles.

Don Quijote by Orson Welles continuously renegotiates the fictional world through. Welles's direction faces the complexity of Cervantes's novel and its narrative and metaartistic mechanisms (Lotman, 1981). We should recall that Cervantes's first book established a conflict between old times (the chivalric romance) and modern $17^{\text {th }}$ century times. And here we find a conflict between a first narrator (the author "Cervantes"), who almost immediately borrows fictitiously the story of a second narrator, and the Arab historian "Cid Hamete Benengeli", often ironically commenting on the lack of reliability of the translation from the Arabic he is using. In Cervantes's second novel, the Adventures of Don Quixote are already known by many characters who have read the first novel. They have also read a false 'sequel' because new Adventures were told in a novel by Avellaneda (which really happened, to the detriment of Cervantes). Welles translates such complexity with some basic choices: the contrast 
between ancient and modern times is conveyed by inserting the exploits of the characters, perfect in their costumes and dialogues, in a contemporary Spain. So Don Quixote may meet a girl on a Vespa scooter, or stand in front of an epic film in a movie theater, trying to cut through the screen with his sword. ${ }^{9}$ Then Welles addresses problems of meta-representation and reflexivity: the practice of shooting enters the story, as does Welles himself, and the result is to certify and at the same time falsify the cinematic discourse and its strategies. This complex textual mechanisms recalls Lotman's proposals regarding the languages of arts as "meta-languages of a culture" and of course "meta-cinema" as a peculiar trend of (post)modernity (1981: 10- 12; see also Lotman and Tsivian, 1994).

The main theme of the relationships between the real and the fantastic, with Quixote lost between what is 'something (that) looks like' and what 'he wishes it to be' also appears in postmodern films of the digital era. To deal with this Don Quixote by Peter Yates (USA, 2000) uses a dense interpolation of new digital scenes, veering towards the fantasy genre. In the sequence of the windmills, the film retrieves the subjective hallucinated gaze of Quixote: the film shows him attacking the enemy while some enormous giants appear with a huge black magician flying over them. Yates's movie thus shows faithfulness to the novel, like Welles's film, but in the clash between Quixote and the windmill it also incorporates Pabst's invention of the knight pulled up by the sails. 


\section{Movie remix}

In the countless proliferation of film-clips on YouTube we can also find some anonymous forms of a particular remix, the 'cliptrailer': a hybrid text between a videoclip and a trailer that takes some scenes and frames from a source film in order to promote a song.

While searching through YouTube for Don Quixote, we might find a quick re-assembly of some key scenes from Welles's film in a cliptrailer paying tribute to a song by the contemporary Italian folk singer Francesco Guccini used as its soundtrack. Guccini's song chronicles the exploits of Don Quixote and Sancho Panza in the form of a philosophy of life in which everyday life is frantic and meaningless and is nostalgic about youth and its illusions. In this remix, obviously containing the scene of the windmills, Welles's film becomes an aesthetic iconic counterpoint of the poetic words of the singer in which Don Quixote becomes a symbol of maladaptation to capitalistic society.

Another cliptrailer which tagged Don Quixote, and I have found to be less successful, uses a static editing of some color photographs from the Seventies of the two singers of the Hungarian group Neoton Familia, followed by some sequences of the musical film Man of La Mancha by Hiller (1972) (with Sophia Loren and Peter O'Toole in the protagonists' roles). Once again the pretext here is a song with a refrain about Don 
Quixote. Both cliptrailers use the Web for some practices of 'found footage' on existing materials. In the first remix, it is above all a soundtrack transformation, while in the second (a mash up) the theme of the knight-errant and his meeting with Dulcinea being used as a kind of 'temporary glue'. The film by Arthur Hiller, even through fragments of this rework, is unexpectedly useful for our research. The choice of the reedited sequences in fact closes with the scene of the windmills in which Pabst's iconic invention returns, in a magnified and expanded form.

In a cliptrailer, the source text can be remixed in such a way as to pay homage to the source movie or to subvert its values and topics instead. Prosumers use their digital skills with a Do-It-Yourself approach, remixing movies mostly as playful selfpromotion but also, sometimes, giving rise to a new æsthetics of re-creation (Bourriaud, 2002; Navas, 2012).

\section{Conclusion}

Adaptations, remakes and movie remixes do not solely reopen the literary Don Quixote by Cervantes but also recycle some cinematic inventions stored in Western cultural memory. Translating always means setting up interpretative procedures of "amplification" and "condensation" (Eco, 1979) or what Lotman calls "ossification" and "softening" processes (Lotman, 1977: 204). These are strategies based on languages flexibility, namely the possibilities for semantic condensation or semantic expansion. 
I consider adaptations and remakes as intermedial processes and remix practices as transmedial ones. Thanks to Lotman's "semiosphere" theory they can be studied as a dialogic cultural ensemble of inter- and intrasemiotic relations among texts.

\section{Notes}

1 Lotman recalls that ambivalence was identified by Bakhtin (1963) as a primarily semiotic and cultural phenomenon, and discerns a number of basic oppositions in every culture.

2 Following Translation Studies (see Toury, 1980) we could call 'source text' the hypotext and 'target text' the hypertext.

3 For example Kattenbelt (2008) claims that "transmediality" refers to the transfer from one medium to another medium (with relevant media changes); and "intermediality" refers to the co-relation of media in the sense of mutual influences between media.

4 According to Manovich (2007) a "remix" is a new text based on pre-existing materials within a logic of cut and paste, but drawn consistently from a single source. When materials are heterogeneous as is the case for medial sources and formats, the definition "mash up" is then used (Navas, 2012; Sonvilla-Weiss, 2010).

5 In textual semiotics, isotopies are guidelines running through any text, given by internal repetition of signs and the internal coherence among them. They can be partial or global, found throughout the whole text (Greimas, 1983). 
6 In this examples I will use the translation by John Ormsby, 1922.

7 "[...] arremetió a todo el galope de Rocinante y embistió con el primero molino que estaba delante, y, dándole una lanzada en el aspa, la volvió el viento con tanta furia que hizo la lanza pedazos, levándose tras sí al caballo y al caballero, que fue rodando muy maltrecho por el campo" (M. De Cervantes Saavedra, El ingegnoso hidalgo Don Quijote de la Mancha, Chap. VIII, vol. I, "Los molinos de viento").

8 We find the same solution in the Italian parody by G. Grimaldi, Don Chisciotte e Sancho Panza (IT, 1968).

9 This one is a missing scene in Franco's version.

\section{References}

Altman R (1999) Film/Genre. London: BFI.

Arvidson J, Askander M, Bruhn J, and Führer H, eds (2007) Changing Borders. Contemporary Positions in Intermediality. Lund: Intermedia Studies Press. Bolter JD, Grusin R (1999) Remediation : Understanding New Media. Cambridge, MA: MIT Press.

Bourriaud N (2002) Postproduction: Culture as Screenplay. How art reprograms the world. Lukas \& Sternberg: New York.

Casetti F (2008) Eye of the Century: Film, Experience, Modernity. New York: Columbia University Press.

Bakhtin MM (1963) Problemy poetiki Dostoevskogo. Moskva (It. Transl. [1968] Dostoevskij. Poetica e stilistica. Turin: Einaudi).

Costa A (2002) Il cinema e le arti visive. Turin: Einaudi.

Davidson D, et al. (2010) Cross-Media Communications: An Introduction to the Art of Creating Integrated Media Experiences. Pittsburgh, PA: ETC Press.

De Cervantes Saavedra M (2000) [1605-1615] Don Quixote of La Mancha. Translation by John Ormsby [1922]. Pennsylvania: The Pennsylvania State University.

Dena C (2009) Transmedia Practice. Theorising the Practice of Expressing a Fictional 
World across Distinct Media and Environments. PhD Thesis, University of Sydney, Sydney.

Dusi N (2000) Introduzione. Per una ridefinizione della traduzione intersemiotica. Versus. Quaderni di studi semiotici 85-86-87: 3-54.

Dusi N (2010) Translating, Adapting, Transposing. ASSA (Applied Semiotics, Sémiotique Appliquée) 24(9): 82-94.

Dusi N (2012) Remaking as a Practice: Some Problems of Transmediality. Cinéma\&Cie. International Film Studies Journal XII(18): 115-127.

Dusi N, Spaziante L, eds. (2006) Remix-Remake: pratiche di replicabilità. Rome: Meltemi. (Also available at: www.ec-aiss.it/biblioteca/biblioteca.php).

Eco U (1979) The Role of the Reader: Exploration in the Semiotics of Texts. Bloomington, IN: Indiana University Press.

Eco U (1990) The Limits of Interpretation. Bloomington, IN: Indiana University Press.

Eco U (2001) Experiences in Translation. Toronto-Buffalo-London: University of Toronto Press.

Eco U, Nergaard S (1997) Semiotic approaches. In: Baker M (ed.) Routledge Encyclopedia of Translation Studies. London-New York: Routledge, 218-222.

Elleström L, ed. (2010) Media Borders, Multimodality and Intermediality. London-New York: Palgrave MacMillan.

Eugeni R (1999) Film, sapere, società. Per un'analisi sociosemiotica del testo cinematografico. Milan: Vita e Pensiero.

Floch JM (2000) Visual identities, London and New York: Continuum.

Fontanille J, Zilberberg C (1998) Tension et signification. Sprimont: Mardaga.

Forgione AP (2005) Don Chisciotte al cinema. Naples: Giannini.

Genette G (1982) Palimpseste: la littérature au second degré. Paris: Seuil.

Greimas AJ (1983) Du sens II. Essais sémiotiques. Paris: Seuil.

Giménez-Frontín JL (2005) De la pedagogía al signo. In: Visiones del Quijote: Hogart, Doré, Daumier, Picasso, Dalí, Matta, Ponç y Saura. Catalogue. Barcelona: Fundació Caixa de Catalunya.

Jakobson R (1959) On linguistic aspects of translation. In: Brower R (ed.) On Translation. Cambridge, MA.: Harvard University Press, 232-239.

Jakobson R (1971) The dominant. In: Matejka L and Pomorska K (eds.) Readings in Russian Poetics: Formalist and Structuralist Views. Cambridge, MA: MIT Press, 82-88. Jenkins H (2006) Convergence Culture. Where Old and New Media Collide. New York and London: New York University Press.

Jenkins H (2007) Transmedia storytelling 101. In: Confessions of an Aca-Fan. The Official Weblog of Henry Jenkins.

Available at: http://www.henryjenkins.org/2007/03/transmedia_storytelling_101.html (accessed 7 November 2013). 
Jenkins H (2011) Transmedia 202: Further Reflections. In: Confessions of an Aca-Fan. The Official Weblog of Henry Jenkins.

Available at: http://henryjenkins.org/2011/08/defining_transmedia_further_re.html (accessed 7 November 2013).

Kattenbelt C (2008) Intermediality in Theatre and Performance. Definitions, Perceptions and Medial Relationships. Culture, Language \& Representation 6(V): 1929.

Kristeva J (1994) On Yuri Lotman. Pubblication of the Modern Language Association (PMLA) 109(3): 375-376.

Lessig L (2008) Remix: Making art and Commerce Thrive in the hybrid Economy. New York: Penguin.

Lévi-Strauss C (1958) Antropologie structurale. Paris: Plon.

Lotman JM (1977) The dinamic model of a semiotic system. Semiotica 21(3/4): 193210.

Lotman JM (1981) [1973] Semiotics of Cinema. Ann Arbor: University of Michigan.

Lotman JM (1984) On the semiosphere. Sign Systems Studies 33(1): 205-229.

Lotman JM ( 1994) [1981] The Text within the Text. Pubblication of the Modern Language Association (PMLA) 109(3): 377-384.

Lotman JM (2001) [1990] Universe of the Mind: A Semiotic Theory of Culture. London - New York: Tauris.

Lotman JM (2009) [1993 ] Culture and Explosion. Berlin: Mouton de Gruyter.

Lotman JM, Tsivian Y (1994) Dialog s ekranom. Tallin: Aleksandra (It. Transl. [2001] Dialogo con lo schermo. Bergamo: Moretti and Vitali).

Manovich L (2001) The Language of New Media. Cambridge (MA): MIT Press.

Manovich L (2007) What Comes After Remix?. Available at: http://Manovich.net (accessed 20 November 2013).

Manovich L (2013) Software Takes Command. London: Bloomsbury Academic.

Marrone G (2009) [2005] Ludovico's cure : on body and music in A clockwork orange. Ottawa - New York: Legas.

Nabokov V (1983) Lectures on Don Quixote. Orlando - Florida: Harcourt Brace Jovanovich.

Navas E (2012) Remix Theory: The Aesthetics of Sampling. Wien: Springer-Verlag. Odin R (2000) De la Fiction. Bruxelles: De Boeke.

Rajewsky I (2005) Intermediality, Intertextuality and Remediation. A Literary Perspective on Intermediality. Intermédialités 6: 49-60.

Riley EC (1988) Don Quixote: from Text to Icon. Bulletin of the Cervantes Society of America. Special Issue (Winter): 104-114..

Reiss K (1983) Adequacy and equivalence in translation. The Bible Translator 3: 208301. 
Sonvilla-Weiss S, ed. (2010) Mashup Cultures. Wien: Springer-Verlag.

Stam R, Burgoyne R, Flitterman-Lewis S (1992) New Vocabolaries in Film Semiotics. Structuralis, Post-structuralism and Beyond. London and New York: Routledge.

Torop P (1995) Total'nyj perevod. Tartu: Tartu University Press (Italian Transl. [2000] La traduzione totale. Modena: Guaraldi Logos).

Torop P (2000) Intersemiosis and Intersemiotic Translation. European Journal for Semiotic Studies 12: 71-100.

Torop P, Saldre M (2012) Trasmedia space. In Ibrus I and Scolari CA (eds.) Crossmedia Innovation : Texts, Markets, Institutions. Frankfurt am Main: Peter Lang GmbH, 25-44.

Toury G (1980) In Search of a Theory of Translation. Tel Aviv: The Porter Institute for Poetics and Semiotics - Tel Aviv University.

Tryon C (2009) Reinventing Cinema. Movies in the Age of Media Convergence. New Brunswick (New Jersey) - London: Rutger University Press.

Wolf W, Bernhart W, eds. (2006) Framing borders in literature and other media. Amsterdam - New York: Rodopi.

\section{Author biography}

Nicola M. Dusi, PhD in Semiotics, is Senior Lecturer of Media Semiotics at the University of Modena and Reggio Emilia (Italy), Department of Communications and Economics. He is the author of the semiotic essay "Il cinema come traduzione" (Turin: Utet, 2003). He edited (with C. Righi) a monographic number of "Degrés" (141, 2010) about "Dance Research and Transmedia Practices".

Email: nicolamaria.dusi@unimore.it 